\title{
Seed provenance matters - Effects on germination of four plant species used for ecological restoration
}

\author{
Armin Bischoff ${ }^{\mathrm{a}, *}$, Beatrice Vonlanthen ${ }^{\mathrm{b}}$, Thomas Steinger ${ }^{\mathrm{a}}$, \\ Heinz Müller-Schärer ${ }^{\mathrm{a}}$
}

\author{
${ }^{a}$ Department of Biology, Unit of Ecology and Evolution, University of Fribourg, Chemin du Musée 10, \\ $\mathrm{CH}-1700$ Fribourg, Switzerland \\ bPresent address: Department of Biology, Institute of Geobotany and Botanical Garden, University of Halle, Halle, \\ Germany
}

\begin{abstract}
Summary
The use of local seed provenances is often recommended in restoration and habitat creation because they are thought to be better adapted to local habitat conditions. However, spatial scales and the degree of population differentiation are not well known and germination is often not included in comparisons between provenances. We analysed germination as a key trait of plant development in five provenances of four species used for ecological restoration on arable land (wildflower strips). Germination was tested under different conditions in growth chambers (early vs. late spring) and in the field (non-competition vs. competition). We also examined the contribution of non-genetic (maternal) effects to population differentiation.

Large differences in germination traits were found between the provenances in growth chambers and in the field. The ranking was species-specific, but largely consistent across all tested environments. Local provenances did not generally exhibit higher germination percentages in the field relative to non-local provenances. Due to the high stability of germination traits across various environments, growth chamber tests provided a reliable prediction for provenance differences in the field. The differences among provenances seemed to be largely genetically determined as the inclusion of seed mass in the analysis to control for maternal effects did not decrease the degree differences between-provenance differences. In one species, however, non-genetic contributions to population differentiation were found by comparing F1 seeds grown under homogeneous conditions and original seed material. We conclude that potentially large between-provenance differences in germination traits need to be considered in ecological restoration projects,
\end{abstract}

*Corresponding author. Tel.: +41 26 3008848; fax: +41 263009698 .

E-mail address: armin.bischoff@unifr.ch (A. Bischoff). 
particularly in non-permanent systems where they may determine vegetation development.

\section{Zusammenfassung}

Für Renaturierungsvorhaben und die Schaffung neuer Habitate wird vielfach die Verwendung von lokalem Saatgut gefordert, da man von einer besseren Anpassung an die lokalen Standortbedingungen ausgeht. Die räumlichen Skalen und das Ausmaß der Populationsdifferenzierung sind jedoch kaum bekannt, und Vergleiche zwischen verschiedenen Herkünften lassen häufig die Keimung unberücksichtigt. Als ein entscheidendes Merkmal der pflanzlichen Entwicklung wurde in der vorliegenden Studie die Keimung für jeweils fünf Herkünfte von vier Arten untersucht, die Bestandteil von Einsaatmischungen zur Wiederherstellung von Biodiversität auf ehemaligen Ackerflächen sind (Buntbrachen). Die Keimung wurde unter verschiedenen Bedingungen in Klimakammern (Vor-versus Spätfrühling) und im Feld (ohne versus mit Konkurrenz) getestet. Desweiteren wurde der Beitrag von nichtgenetischen (maternellen) Effekten zur Populationsdifferenzierung geprüft.

Sowohl in Klimakammern als auch im Feld wurden große Unterschiede im Keimverhalten der verschiedenen Herkünfte festgestellt. Die Rangfolge der Herkünfte war artspezifisch, aber weitgehend konsistent unter allen getesteten Bedingungen. Die lokalen Herkünfte zeigten im Feld keine generell höhere Keimung als die fremden. Aufgrund der hohen Stabilität der Keimungseigenschaften unter verschiedenen Umweltbedingungen ermöglichten die Klimakammerversuche eine zuverlässige Prognose von Herkunftsunterschieden im Feld. Die Einbeziehung des Samengewichtes zur Kontrolle von maternellen Effekten in der statistischen Analyse veränderte die Größenordnung der Herkunftsunterschiede nicht, so dass eine weitgehend genetisch bedingte Differenzierung angenommen werden kann. Ein Vergleich von Ausgangs- und F1-Saatgut, das unter einheitlichen Bedingungen nachgebaut wurde, belegte jedoch auch die Beteiligung von nicht-genetischen Effekten an der Populationsdifferenzierung. Die Ergebnisse legen nahe, dass die potenziell großen herkunftsbedingten Unterschiede im Keimverhalten bei Renaturierungsprojekten berücksichtigt werden sollten. Das gilt insbesondere für kurzlebige Systeme, in denen solche Unterschiede die Vegetationsentwicklung bestimmen können.

\section{Introduction}

The provenance of seed material used in ecological restoration or habitat creation is subject of an ongoing debate (Hamilton, 2001; Hufford \& Mazer, 2003; Wilkinson, 2001). Local provenances are often recommended because they are expected to be better adapted to local site conditions facilitating vegetation establishment. Apart from insufficient establishment the use of non-local seed provenances might involve environmental risks such as cryptic invasions of superior genotypes (Saltonstall, 2002) or outbreeding depression, i.e. a reduction in hybrid fitness following gene flow from alien into local populations (Keller, Kollmann, \& Edwards, 2000; Montalvo \& Ellstrand, 2001). Indeed, plant populations often exhibit pronounced genetic differentiation in fitness-related traits resulting from habitat-specific selection or genetic drift (reviewed by Linhart \& Grant, 1996), but spatial scales and degree of differentiation at which negative consequences of genotype introduction can be expected are less known. For example, a home-site advantage of the local population was demonstrated already at the level of plant communities (van Tienderen, 1992) or local scales (Kindell, Winn, \& Miller, 1996, $8 \mathrm{~km}$ ) whereas other studies failed to find local adaptation at much larger scales (Galloway \& Fenster, 2000: $\sim 1000 \mathrm{~km}$ ).

Germination is one trait that has been found to greatly vary among populations (reviewed by Baskin \& Baskin, 1998). Selection is expected to favour appropriate responses to local environmental cues that synchronise germination with periods that are optimal for seedling survival. Such a selection may result in site-specific adaptation of germination traits. In a reciprocal transplant experiment with 
Gilia capitata from coastal and inland habitats, germination percentage of the local population was higher at both sites (Nagy \& Rice, 1997). In a common garden experiment on species used for ecological restoration germination was negatively correlated to geographical distance (Keller \& Kollmann, 1999). However, in other cases, no consistent geographical patterns were found that could be related to environmental conditions (Cousens, Armas, \& Baweja, 1994; Schütz \& Milberg, 1997).

In ecological restoration schemes, germination traits are of particular importance in non-permanent systems in which the success is largely dependent on seedling emergence. Designed for a period of two to six years, sown wild flower strips are an example of such non-permanent restoration sites. They have been implemented in Switzerland as ecological compensation areas to restore species richness in agricultural landscapes since 1994 and cover currently 2300 ha in 2500 different farms (Swiss Federal Office for Agriculture 2003).

To predict restoration success in terms of establishment and potential environmental risks, more information on genetic differentiation within sown species is required. We studied five provenances of four species of the Swiss wildflower strip in growth chamber and field experiments to quantify population differentiation in germination traits and the effect of geographical distance. Most studies on genetic differentiation have been conducted under non-competitive conditions assuming that the ranking of the populations remains the same under natural competitive conditions (Bennington \& McGraw, 1995; Joshi, Schmid, Caldeira, Dimitrakopoulos, Good et al., 2001; Keller \& Kollmann, 1999). However, such a correlation may be weak or absent (Bossdorf, Prati, Auge, \& Schmid, 2004) and we therefore compared germination in monocultures and in the typical wildflower strip community. Germination tests of provenances under both different lab and field conditions have rarely been done so far but they are required to obtain information on adaptive variation as well as on the stability of differentiation within species.

A methodological constraint of many studies on genetic population differentiation is the confounding of genetic and non-genetic sources of variation. Differences among provenances, particularly in germination, can be inflated by heterogeneous environmental conditions among sites at which seeds were collected (environmental maternal effects: Gutterman, 1992; Lopez, Potts, Vaillancourt, \& Apiolaza, 2003; Pico, Ouborg, \& van Groenendael, 2003; Roach \& Wulff, 1987). In order to evaluate the importance of non-genetic effects, we (a) used seed mass (known to be largely affected by the maternal environment) as a covariate in the analysis of a subset of seeds, and we (b) repeated germination experiments with one of the species (Legousia speculum-veneris) using F1 seeds produced under homogeneous conditions. The following specific questions were addressed:

1. Do the provenances of the four test species differ in germination percentage and time?

2. Does among-provenance differentiation depend on environmental conditions such as (a) climate simulated in growth chambers, (b) growth chamber versus field conditions and (c) competitive vs. non-competitive conditions in the field?

3. Do non-genetic factors (e.g. environmental maternal effects) contribute to the amongpopulation variation?

\section{Material and methods}

\section{Study species and seed provenance}

Four species from a seed mixture used for wildflower strips in Switzerland were selected based on the following criteria: (1) they represent different stages of the succession, (2) they are available from European regions with Atlantic and continental climate, (3) a confounding of different subspecies can be excluded. Legousia speculumveneris (L.) CHAIX (Campanulaceae) was selected as a rare arable plant that reaches maximum abundance in the first year of the wildflower strip development. Echium vulgare L. (Boraginaceae) and Cichorium intybus L. (Asteraceae) are ruderal species that represent the early succession after the first year. Echium vulgare is a typical biennial plant forming rosettes in the first year and flowering in the second year. C. intybus is a predominantly perennial plant but there are also biennial populations. Origanum vulgare L. (Lamiaceae) usually occurs in open forests or forest edges. As a clonally growing perennial it is a characteristic species of later stages in wildflower strip succession. All species are predominantly pollinated by insects but in L. speculum-veneris, $E$. vulgare and C. intybus selfing is also possible.

One "local" and four "non-local" provenances were selected based on geographical and environmental distances to the field site (Table 1). The "local" Western Swiss provenance, the Eastern Swiss (East $\mathrm{CH}$ ) and the Southern German one (South $D$ ) are characterised by a suboceanic climate 
Table 1. Source of seed material, localities, distance from the experimental site and climate

\begin{tabular}{|c|c|c|c|c|c|c|}
\hline & Source & Collection site & Distance $(\mathrm{km})$ & Climate & $\begin{array}{l}\text { Temp. Jan/ } \\
\text { Jul }\left({ }^{\circ} \mathrm{C}\right)\end{array}$ & $\begin{array}{l}\text { Rainfall } \\
\left(\mathrm{mm}^{*} \mathrm{a}^{-1}\right)\end{array}$ \\
\hline West $\mathrm{CH}$ & Own collection & Region Fribourg & Local $(<10)$ & Suboceanic & $\begin{array}{r}0.5-1.0 / \\
16.5-17.5\end{array}$ & $1000-1200$ \\
\hline East $\mathrm{CH}$ & Fenaco, ltd & Region Winterthur & $120-200$ & Suboceanic & $\begin{array}{r}0.5-1.0 / \\
16.5-17.5\end{array}$ & $1050-1250$ \\
\hline South D & Appel, ltd & $\begin{array}{l}\text { South Hesse }{ }^{a} \text { North } \\
\text { Baden }{ }^{b, c, d}\end{array}$ & $300-450$ & Suboceanic & $\begin{array}{r}0.5-1.0 / \\
17.0-18.0\end{array}$ & $650-850$ \\
\hline Central D & Own collection & $\begin{array}{l}\text { Regions Halle }{ }^{\mathrm{a}, \mathrm{c}} \\
\text { and Naumburg }\end{array}$ & $600-650$ & Subcontinental & $\begin{array}{l}-0.5-0.0 / \\
17.5-18.0\end{array}$ & $450-500$ \\
\hline West EUR & $\begin{array}{l}\text { (a) Emorsgate, ltd, } \\
\text { UK } \\
\text { (b) Botanical Garden }\end{array}$ & $\begin{array}{l}\text { Sommerset }^{a}, \\
\text { Norfolk }^{d} \\
\text { Region Bordeaux }\end{array}$ & $\begin{array}{l}750-900 \\
600-700\end{array}$ & $\begin{array}{l}\text { Oceanic } \\
\text { Oceanic }\end{array}$ & $\begin{array}{c}4.0-5.0 / \\
16.5-17.5 \\
5.0-5.5 / \\
19.5-20.0\end{array}$ & $\begin{array}{l}650-850 \\
850-950\end{array}$ \\
\hline
\end{tabular}

${ }^{\mathrm{a}}$ Echium vulgare.

${ }^{\mathrm{b}}$ Legousia speculum-veneris.

${ }^{\mathrm{C} C i c h o r i u m ~ i n t y b u s .}$

'Origanum vulgare.

similar to that of the field site. The Central German provenance (Central D) originates from a more continental climate with much lower rainfall and the Western European provenances (West EUR) represent a typical oceanic climate with mild winter temperatures. L. speculum-veneris seed were not available from Central Germany because the species has become extremely rare in the continental parts of Europe.

Western Swiss and Central German provenance were collected by hand from natural populations. The Western Swiss provenance was sampled from the largest populations that could be found close to the field site. Population sizes were 200 (L. speculumveneris), 300 ( $E$. vulgare), 150 (C. intybus) and 150 (O. vulgare) for the Western Swiss provenance, and 500 (E.vulgare), 400 (C. intybus) and 5000 (O. vulgare) for the Central German one. To ensure a genetic diversity representative of a population, seeds of each species were sampled from 50 randomly chosen mother plants that were at least $5 \mathrm{~m}$ apart. The seeds were stored at room temperature until sowing in the following spring. The other non-local provenances were provided by commercial suppliers. Only companies were chosen who could present information on the original collection site and who regularly replace stocks by wild collections from populations larger than 200 individuals. The companies guaranteed that seeds were not selected for size and that they were stored at room temperature for not longer than two years. Seeds from a Western European supplier (The Netherlands) of $L$. speculumveneris that did comply with these requirements were later identified as Legousia pentagonia and had to be omitted from the analyses.

\section{Germination experiments}

\section{Growth chamber experiment}

Seeds were placed in Petri-dishes filled with a $0.5 \mathrm{~cm}$ layer of Agar (1\% Agar No. 1, Oxoid Ltd). Using growth chambers of the same type (Sanyo Growth Cabinet MLR-350H), two climatic conditions were applied to examine the environmental dependency of the provenance effect. One growth chamber simulated early spring conditions, i.e. $13 \mathrm{~h}$ dark, $5^{\circ} \mathrm{C}$ and $11 \mathrm{~h}$ light, $15^{\circ} \mathrm{C}$, the other late spring conditions, i.e. $11 \mathrm{~h}$ dark, $10^{\circ} \mathrm{C}$ and $13 \mathrm{~h}$ light, $20^{\circ} \mathrm{C}$. The Petri-dishes were arranged randomly within growth chambers and the simulated climatic conditions were changed between the chambers in a second run of the experiment. Petri-dishes contained 50 seeds of one provenance and in each run, four replicate Petridishes of each species $\times$ provenance $\times$ climate combination were used for a total of 304 Petri-dishes (4 species $\times 5$ provenances [L. speculum-veneris: 3$] \times 2$ climates $\times 2$ chambers $\times 4$ Petri-dishes $\times 50$ seeds). Germinated seeds were counted every second day and then removed. A seed was considered as germinated when the radicule was visible. The experiment was started in April 2002, and in each run germination was recorded for 30 days. Almost no further germination occurred afterwards in Petri-dishes kept for prolonged observation.

\section{Field experiment}

In April 2002, seeds were sown into $2 \times 2 \mathrm{~m}^{2}$ plots of a previously ploughed and harrowed arable field $10 \mathrm{~km}$ north of Fribourg in western Swiss midlands. Germination from the local seed bank could be 
excluded because none of the species occurred in the field or adjacent margins prior to the experiment. Each plot comprised seeds of one provenance $\times$ species combination sown in a central grid of 24 cells $\left(0.2 \times 0.2 \mathrm{~m}^{2}\right)$ with six seeds $(0$. vulgare: $10)$ per grid cell. The higher number was chosen in $O$. vulgare because seeds are very small and show a high mortality in the soil (Pons, 1991). For the competition treatment half of the plots were additionally sown with the usual wildflower strip seed mixture that comprises 24 species in a total density of 600 seeds $/ \mathrm{m}^{2}$. There was a total of 304 plots arranged in a randomised block design with 8 blocks $(4$ species $\times 5$ provenances [ $L$. speculumveneris: 3] $\times 2$ competition $\times 8$ blocks $\times 24$ grid cells). Seedling emergence was recorded five and ten weeks after sowing and at each census the nocompetition plots were weeded.

\section{Tests for non-genetic effects}

\section{Contribution of seed mass to between-provenance variation}

Differences in environmental conditions of the collection sites (maternal environment) could have led to non-genetic differences in seed mass which in turn may have affected between-provenance variation in germination percentage. To test for such non-genetic effects on germination, seed mass was used as a covariate in models with germination percentage as dependent variable (see Statistical Analysis). Single seed mass was measured in a random subset of seeds used in the growth chamber experiment ( 5 out of the 50 seeds per Petri-dish).

\section{Second-generation seed of Legousia speculum-veneris}

To obtain further information on non-genetic contributions to among-provenance variation, the original seed material of $L$. speculum-veneris was compared to F1 seeds produced under homogeneous conditions in a common garden. Sixty seedlings of each provenance randomly chosen from the growth chamber experiment were planted into pots and placed in the greenhouse. Juvenile plants were transferred to five garden plots each comprising 12 plants of one provenance for a total of 15 plots ( 3 provenances $\times 5$ plots). The plots were randomly arranged to avoid a confounding of provenance and site conditions. Before the onset of flowering the plots were caged with Nylon mesh $(1 \mathrm{~mm}$ mesh size) to avoid cross-pollination between the provenances. One provenance was always left uncovered for five days to allow random pollination of the insect-pollinated plants (predo- minantly by bumble bees and syrphids). Every five days the previously uncovered provenance was caged again and cages were removed from another provenance. In August the capsules were harvested and a mixed sample of all seeds from each provenance was tested in a second growth chamber experiment using the same set up as in the first one. The F1 seeds were also sown in a second field experiment starting in the following spring. We followed the described procedure, except that we placed ten instead of six seeds into each grid cell.

\section{Statistical analysis}

In the growth chamber experiment the effects of provenance and climate on the response variables germination percentage and time were tested using ANOVA. Germination percentage is the fraction of seeds germinated in each Petri-dish after 30 days of incubation, germination time is the mean number of days to germination. Chamber (nested within climate) was introduced as a random factor to control for differences between the two series of the experiments. The factor includes variation due to differences between growth chambers and due to the different storage time until the first and the second run of the experiment. For calculating $F$ values, climate was tested over the chamber effect, whereas provenance and the climate-byprovenance interaction were tested over the error term. To achieve normality and homogeneity of variances, germination percentage was arcsin square root transformed and germination time was log transformed prior to analysis.

In the field experiment only germination percentage was used as response variable. ANOVA was performed on arcsin square root transformed block means (i.e. mean of 24 grid cells per plot) using seed provenance, competition and block as fixed factors (unreplicated block design).

In both experiments the Tukey HSD test was used for multiple comparisons of the means. All analyses were calculated separately for each species as the full model revealed a significant species by provenance interaction. For each species the correlation between germination in growth chambers and in the field was calculated using Pearson's correlation coefficients of provenance means.

Between-provenance differences in seed mass (subset of seeds) were analysed in a one-way ANOVA. The contribution of seed mass to the between-provenance variation in germination was tested in a generalised linear mixed model specifying binomial errors and a logit link function (GLIMMIX macro of SAS) because analysis had to 
be applied to germination of individual seed, not on Petri-dish means as in the ANOVA models mentioned above. Petri-dish was used as an additional factor nested in provenance and climate. The full model including seed mass as a covariate was compared to a reduced model without covariate.

To compare the provenance effect on germination of $L$. speculum-veneris in parental and $F 1$ seeds, ANOVA models were run that additionally included generation as a fixed factor. Because seeds of the two generations were tested in separate experiments, the generation main effect may be confounded with environmental factors. Therefore, the analysis focused on the generation by provenance interaction. A significant interaction resulting in a reduced between-provenance variation in the $\mathrm{F} 1$ was interpreted as evidence for non-genetic effects.

\section{Results}

\section{Provenance effects in growth chambers and in the field}

In the growth chamber experiment, differences in germination percentages between the seed provenances were highly significant for all species (Table 2A). There was no consistent pattern among species in the ranking of the provenances and the differences between them (Fig. 1). In C. intybus and $L$. speculum-veneris, the highest germination occurred in the Eastern Swiss provenance and the lowest in the Western Swiss one. In E. vulgare germination percentage was also the highest in the Eastern Swiss provenance but the lowest in the Western European one. Both German provenances of $O$. vulgare germinated the best and again the lowest germination was recorded in the Western European one. There was no general difference in germination of hand-collected seeds and seeds from commercial suppliers. Over all species, one hand-collected provenance (western Swiss) showed a relatively poor germination but the other one (central German) germinated well.

The differences in germination time were significant between the seed provenances of three species (Table 2B). Due to high variation of the within provenance data the provenance effect on the germination time of $E$. vulgare was not significant. The ranking of the provenances was negatively related to the corresponding

Table 2. ANOVA on the effect of seed provenance on germination traits

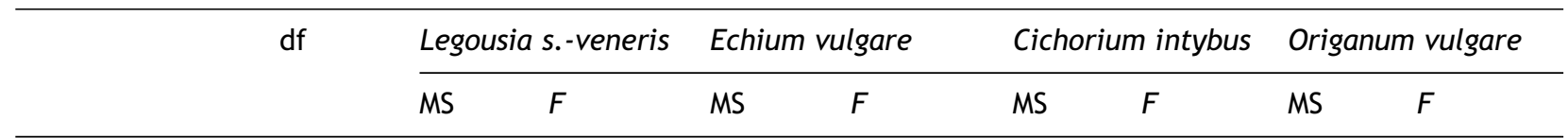

(A) Germination percentage in growth chambers: the effect of seed provenance and climatic conditions (simulation of early spring versus late spring) using arcsin $\sqrt{ }$ transformed proportion data

$\begin{array}{lllccccccc}\text { Provenance } & 4(2) & 0.734 & 116.2^{* * *} & 0.572 & 92.6^{* * *} & 0.139 & 11.1^{* * *} & 0.713 & 71.3^{* * *} \\ \text { Climate } & 1 & 0.815 & 39.4^{*} & 0.713 & 122.1^{* *} & 0.241 & 1.8 & 0.416 & 4.5 \\ \text { Chamber(Clim.) } & 2 & 0.021 & 3.3^{*} & 0.006 & 0.9 & 0.132 & 10.5^{* * *} & 0.093 & 9.3^{* * *} \\ \text { Prov. } \times \text { Climate } & 4(2) & 0.009 & 1.4 & 0.028 & 4.5^{* *} & 0.016 & 1.3 & 0.036 & 3.6^{*} \\ \text { Error } & 68(39) & 0.006 & & 0.006 & & 0.013 & & 0.010\end{array}$

(B) Germination time in growth chambers: the effect of seed provenance and climatic conditions (simulation of early spring versus late spring) using log-transformed number of days required for germination

$\begin{array}{llllllllll}\text { Provenance } & 4(2) & 0.008 & 4.5^{*} & 0.011 & 0.9 & 0.158 & 26.5^{* * *} & 0.179 & 42.6^{* * *} \\ \text { Climate } & 1 & 0.200 & 11.8 & 0.359 & 37.9^{* *} & 0.949 & 17.8 & 0.891 & 9.3 \\ \text { Chamber(Clim.) } & 2 & 0.017 & 9.1^{* * *} & 0.022 & 0.7 & 0.053 & 9.0^{* * *} & 0.096 & 22.9^{* * *} \\ \text { Prov. } \times \text { Climate } & 4(2) & 0.003 & 1.5 & 0.012 & 1.8 & 0.009 & 1.6 & 0.014 & 3.1^{*} \\ \text { Error } & 68(39) & 0.002 & & 0.009^{a} & & 0.006 & & 0.004\end{array}$

(C) Germination percentage in the field: the effect of seed provenance and competition (weeding versus sowing of a plant community) using arcsin $\sqrt{ }$ transformed proportion data

$\begin{array}{llllllllll}\text { Provenance } & 4(2) & 0.604 & 62.6^{* * *} & 0.245 & 69.6^{* * *} & 0.093 & 24.1^{* * *} & 0.075 & 19.2^{* * *} \\ \text { Competition } & 1 & 0.002 & 0.2 & 0.082 & 23.2^{* * *} & 0.023 & 6.1^{*} & 0.010 & 2.4 \\ \text { Prov. } \times \text { Comp. } & 4(2) & 0.014 & 1.4 & 0.006 & 1.7 & 0.008 & 2.0 & 0.001 & 0.2 \\ \text { Block } & 8 & 0.031 & 3.2^{*} & 0.033 & 9.3^{* * *} & 0.026 & 6.7^{* * *} & 0.007 & 1.9 \\ \text { Error } & 63(35) & 0.010 & & 0.004 & & 0.004 & & 0.004 & \end{array}$

Five provenances of Echium vulgare, Cichorium intybus and Origanum vulgare were tested and three provenances of Legousia speculum-veneris ( $\mathrm{df}$ in parentheses)

${ }^{*} P<0.05$, ** $P<0.01$, *** $P<0.001$.

${ }^{a} \mathrm{df}$ error $=59$ due to correction for missing values (i.e. germination $\%=0$ ). 

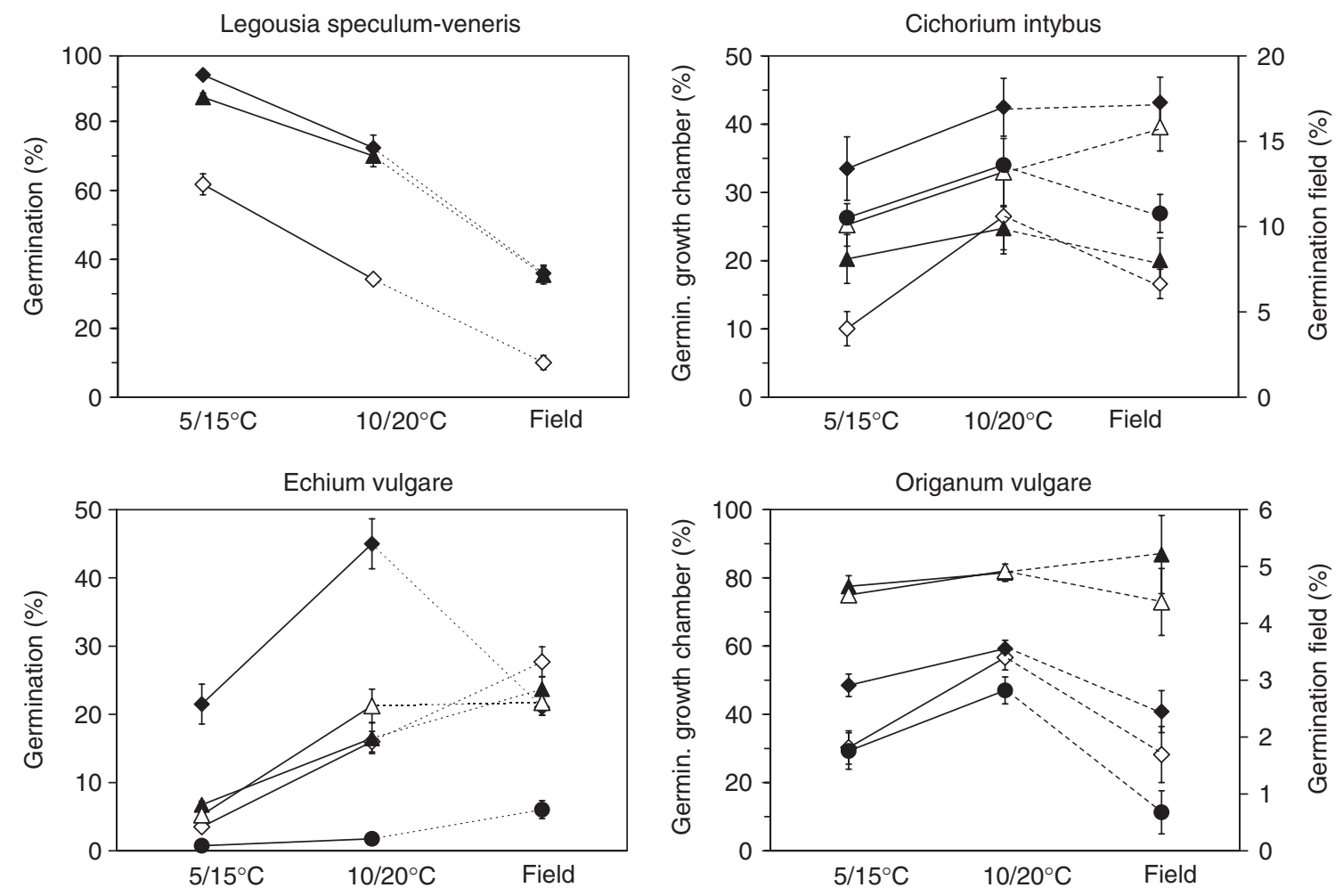

Figure 1. Effect of seed provenance on germination percentage in growth chambers (simulation of early $\left[5 / 15^{\circ} \mathrm{C}\right]$ and late spring conditions $\left[10 / 20^{\circ} \mathrm{C}\right]$ ) and in the field; note the different scales for germination of Cichorium intybus and Origanum vulgare in growth chambers and in the field; $\diamond$, West $\mathrm{CH}$; $\diamond$, East $\mathrm{CH} ; \boldsymbol{\Delta}$, South $\mathrm{D} ; \triangle$, Central D; $\bullet$, West EUR; \pm SE.

germination percentage, i.e. the provenances with the highest germination percentage had the shortest time to germination (Figs. 1 and 2). As an exception the Western Swiss seeds revealed an average germination time although germination percentage was rather low.

Climate affected the germination percentage of $L$. speculum-veneris and $E$. vulgare significantly as well as the germination time of $E$. vulgare (Tables 2A and B). More $L$. speculum-veneris seeds germinated under early spring conditions but fewer $E$. vulgare seeds as compared to late spring conditions (Fig. 1). E. vulgare germinated significantly faster under late spring conditions (Fig. 2). The same tendency was also found for the other species but it was only marginally significant $(P<0.1)$.

The interaction of climate and provenance was significant in germination percentage of $E$. vulgare and $O$. vulgare (Table 2A). In E. vulgare, the Western European provenance did not germinate better under late spring conditions as the other provenances did. In $O$. vulgare, the shift to a higher germination under late spring conditions was stronger in the Western Swiss provenance than in the other ones. The same trend was observed in C. intybus, but the climate by provenance interac- tion was not significant. In the ANOVA on germination time, the climate by provenances interaction was only significant in $O$. vulgare and no consistent trend was found (Table 2B).

In the field experiment, the provenance effect on germination percentage was highly significant (Table $2 \mathrm{C}$ ). In $L$. speculum-veneris, $C$. intybus and $O$. vulgare, the ranking of the provenances was nearly the same as in the growth chamber experiment (Fig. 1). Germination was generally much lower in the field but there was a high correlation to germination in growth chambers (Fig. 3). A different pattern was recorded for E. vulgare. The germination percentage in the field was higher than in growth chambers except for the Eastern Swiss provenance that showed the highest germination of all provenances in the growth chamber but only average germination in the field (Fig. 1). Instead, germination of the local Western Swiss provenance, although significantly lower than Eastern Swiss in the growth chamber, was the highest in the field. For this species, there was no correlation between germination in the field and germination in growth chambers (Fig. 3).

The competition treatment affected only the germination of the late emerging species, $E$. 

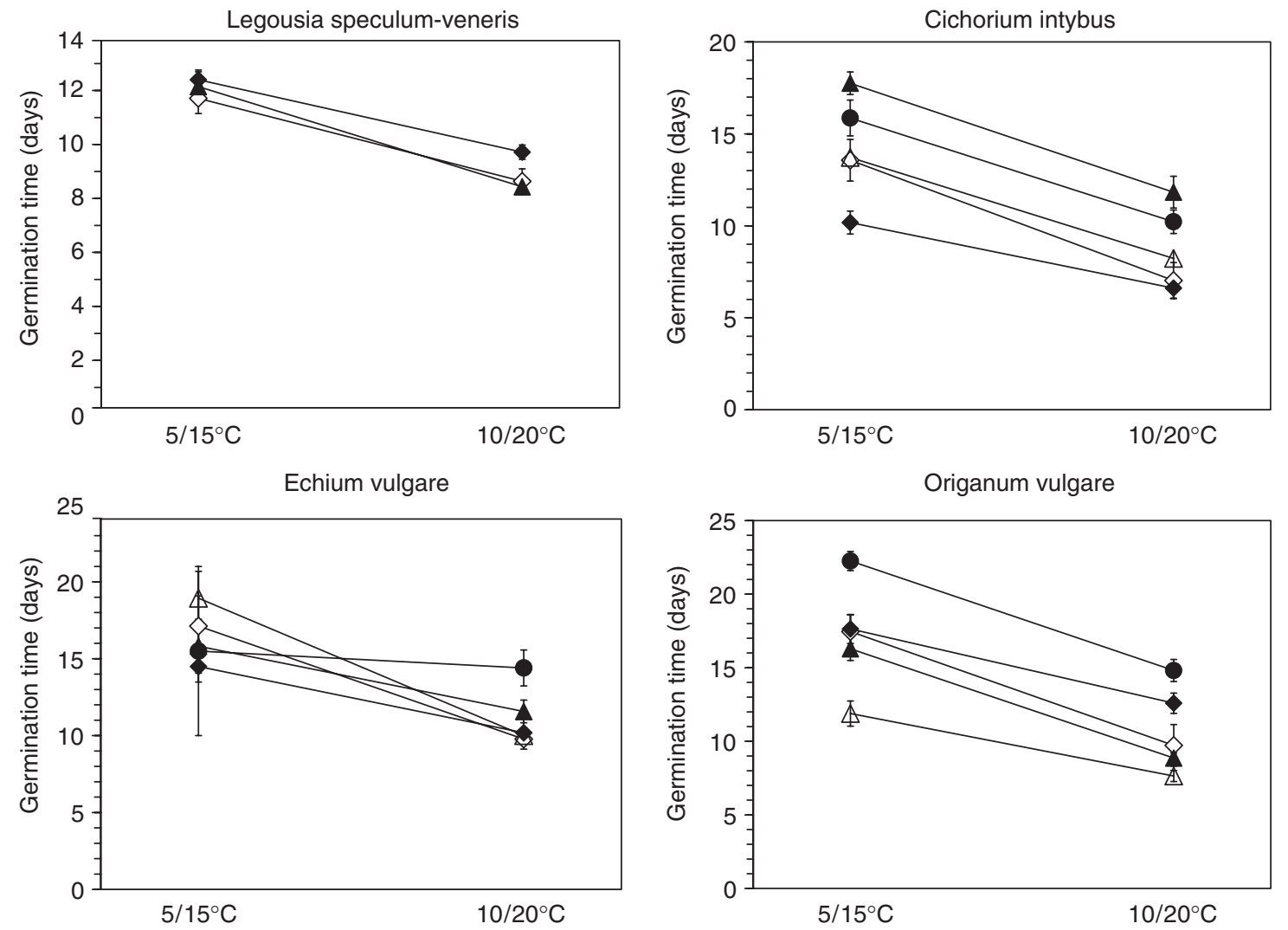

Figure. 2. Effect of seed provenance on germination time, i.e. mean number of days required for germination in growth chambers; simulation of early $\left(5 / 15^{\circ} \mathrm{C}\right)$ and late spring conditions $\left(10 / 20^{\circ} \mathrm{C}\right) ; \diamond$, West $\mathrm{CH} ; \bullet, \mathrm{East} \mathrm{CH} ; \boldsymbol{\Delta}$, South D; $\triangle$, Central D; $\bullet$, West EUR; \pm SE.

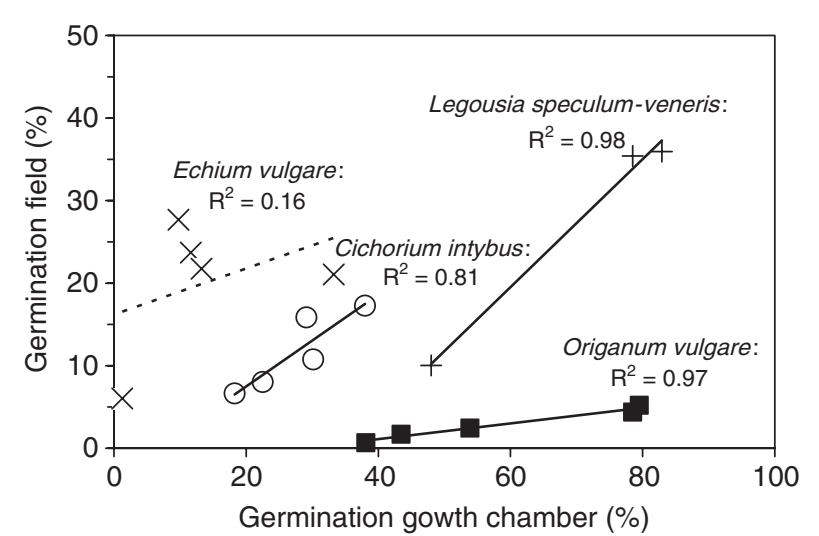

Figure. 3. Correlation between germination in growth chambers and in the field; data points represent provenance means that are pooled for climate (growth chamber) and competition (field); dashed line: not significant; continuous line: significant $(P<0.05, L$. speculum-veneris: $P=0.06$ ).

vulgare and $C$. intybus (Table $2 \mathrm{C}$ ). Germination of these species was lower in competition to a plant community than in weeded monocultures. The interaction of provenance and competition was not significant indicating that the provenance effect was stable and, therefore, only the pooled data were presented in the figures.

\section{Test for non-genetic effects}

Differences in seed mass were highly significant between provenances (Table 3 ). The ranking of the provenances was consistent with germination percentage in $L$. speculum-veneris and $O$. vulgare, i.e. seed mass was the highest in provenances with the highest germination. However, in $E$. vulgare and $C$. intybus the highest seed mass was observed in provenances with the lowest and second lowest (West EUR and South D) germination.

In a statistical model including provenance and climate as factors and seed mass as covariate, germination percentage of $C$. intybus and $O$. vulgare were positively correlated to seed mass (Table 4). There was no correlation of seed mass and germination in $L$. speculum-veneris and a negative one in $E$. vulgare. Fitting of seed mass did not markedly change the $P$-values of provenance, climate and their interaction as compared 
to a model without covariate. Probably due to the reduced sample size, some effects that were significant in the full data set (Table 2A) were not significant in the subset.

The test of F1 seeds from L. speculum-veneris plants grown under homogeneous conditions revealed a generally lower germination as compared to the parental seeds resulting in a significant generation main effect (Table 5, Fig. 4). The provenance main effect remained significant in the growth chamber experiment but not in the field. In both experiments, the provenance-bygeneration interaction was significant. This interaction was due to the differential response of the Western Swiss provenance in which germination percentage remained nearly constant in both generations (particularly in the field) whereas germination of the other provenances was much higher in the parental generation. The ranking of Eastern Swiss and Southern German provenance was the same in both generations.

\section{Discussion}

\section{Between-provenance differences and stability in different environments}

Large differences in germination traits were found between five seed provenances of the four test species. Germination percentage differed by factors of 3 (L. speculum-veneris, C. intybus) to 10 (E. vulgare), germination times by factors of 0.2 ( $L$. speculum-veneris) to 2 (O. vulgare). Similar or even larger differences between populations or provenances were found by Keller and Kollmann (1999), Schütz and Milberg (1997), and Shimono and Kudo (2003) whereas much smaller differences occurred in studies by Nagy and Rice (1997) and Galloway and Fenster (2000).

Population differentiation in plant traits may be caused by evolutionary processes such as differential selection, genetic drift and different levels of inbreeding (Galloway \& Fenster, 2000; Linhart \& Grant, 1996). If selection is strong enough to overcome the homogenising effect of gene flow, adaptation to local site conditions may occur (Linhart \& Grant, 1996). Local adaptation is usually examined in reciprocal transplant experiments but germination is rarely tested because populations are usually planted rather than sown into the experimental sites. In a study on two subspecies of Gilia capitata, one from a coastal and one from an inland site, a home-site advantage in germination percentage was observed in the second year but not in the first (Nagy \& Rice, 1997). No evidence for adaptation in germination traits to the local environment was found in reciprocal transplants of Hordeum spontanum from desert and Mediterranian habitats (Volis, Mendlinger, \& Ward, 2002).

Table 3. Average seed mass $(\mathrm{mg})$ in a subset of 80 seeds per provenance $( \pm \mathrm{SE})$ and ANOVA on provenance effect

\begin{tabular}{lllll}
\hline & Legousia s.-veneris & Echium vulgare & Cichorium intybus & Origanum vulgare \\
\hline West CH & $0.229 \pm 0.007^{\mathrm{a}}$ & $2.894 \pm 0.072^{\mathrm{b}, \mathrm{c}}$ & $1.178 \pm 0.052^{\mathrm{b}}$ & $0.086 \pm 0.004^{\mathrm{a}}$ \\
East CH & $0.248 \pm 0.004^{(\mathrm{b})}$ & $2.918 \pm 0.080^{\mathrm{b}, \mathrm{c}}$ & $1.292 \pm 0.046^{\mathrm{b}, \mathrm{c}}$ & $0.085 \pm 0.003^{\mathrm{a}}$ \\
South D & $0.237 \pm 0.006^{\mathrm{a},(\mathrm{b})}$ & $2.657 \pm 0.085^{\mathrm{a}, \mathrm{b}}$ & $1.399 \pm 0.048^{\mathrm{c}}$ & $0.094 \pm 0.003^{\mathrm{a}}$ \\
Central D & - & $2.538 \pm 0.075^{\mathrm{a}}$ & $1.179 \pm 0.040^{\mathrm{b}}$ & $0.121 \pm 0.004^{\mathrm{b}}$ \\
West EUR & - & $3.121 \pm 0.079^{\mathrm{c}}$ & $0.922 \pm 0.040^{\mathrm{a}}$ & $0.084 \pm 0.003^{\mathrm{a}}$ \\
Origin effect & $F_{2,237}=2.75^{(*)}$ & $F_{4,395}=8.65^{* * *}$ & $F_{4,395}=15.39^{* * *}$ & $\mathrm{~F}_{4,395}=25.97^{* * *}$
\end{tabular}

Different letters behind values indicate significant differences $(P<0.05)$ between provenances within species in multiple comparisons (Tukey HSD). ${ }^{(*)} P=0.066,{ }^{* * *} P<0.001{ }^{\text {a }}$ versus ${ }^{(\mathrm{b})} P=0.051$.

Table 4. Change in $P$-values of generalised linear models on germination percentage by fitting seed mass as a covariate in the subset of weighed seeds

\begin{tabular}{|c|c|c|c|c|c|c|c|c|c|}
\hline & \multirow[t]{2}{*}{ df } & \multicolumn{2}{|c|}{ Legousia s.-veneris } & \multicolumn{2}{|c|}{ Echium vulgare } & \multicolumn{2}{|c|}{ Cichorium intybus } & \multicolumn{2}{|c|}{ Origanum vulgare } \\
\hline & & - covar. & + covar. & - covar. & + covar. & - covar. & + covar. & - covar. & + covar. \\
\hline Seed mass & 1 & & 0.638 & & $<0.001 \downarrow$ & & $0.048 \uparrow$ & & $<0.001 \uparrow$ \\
\hline Provenance & $4(2)$ & $<0.001$ & $<0.001$ & 0.036 & $<0.001$ & 0.111 & 0.060 & $<0.001$ & 0.001 \\
\hline Climate & 1 & 0.007 & 0.007 & 0.997 & 0.996 & 0.127 & 0.124 & 0.231 & 0.274 \\
\hline Prov. $\times$ Climate & $4(2)$ & 0.587 & 0.587 & 0.625 & 0.489 & 0.481 & 0.510 & 0.648 & 0.632 \\
\hline
\end{tabular}

$\uparrow / \downarrow$ indicate a significant positive/negative effect of the covariate on the response variable; fitted but not included in the table: chamber (within climate), Petri dish (within prov. $\times$ climate). 
However, local adaptation is not always simple to demonstrate for germination traits, because low germination fractions and prolonged dormancy, even under conditions favourable for germination, can be adaptive in populations that face high

Table 5. Comparison of the seed provenance effect on germination percentage in the parental generation of Legousia speculum-veneris and in the F1 generation produced under homogeneous conditions in common garden plots; ANOVA with $\arcsin \sqrt{ }$ transformed proportion data

\begin{tabular}{lrcc}
\hline & df & MS & \multicolumn{1}{l}{$F$} \\
\hline (A) Growth chambers & & & \\
Generation & 1 & 5.650 & $232.7^{* * *}$ \\
Provenance & 2 & 0.607 & $25.0^{* * *}$ \\
Climate & 1 & 0.400 & 0.3 \\
Chamber $($ Climate) & 2 & 1.150 & $47.4^{* * *}$ \\
Generation $\times$ Provenance & 2 & 0.172 & $7.1^{* * *}$ \\
Generation $\times$ Climate & 1 & 0.477 & $19.6^{* * *}$ \\
Provenance $\times$ Climate & 2 & 0.015 & 0.6 \\
Gener. $\times$ Prov. $\times$ Climate & 2 & 0.009 & 0.4 \\
Error & 81 & 0.024 & \\
(B) Field & & & \\
Generation & 1 & 1.192 & $128.4^{* * *}$ \\
Provenance & 2 & 0.284 & $30.5^{* * *}$ \\
Competition & 1 & 0.023 & 2.5 \\
Block & 7 & 0.015 & 1.7 \\
Generation $\times$ Provenance & 2 & 0.321 & $34.6^{* * *}$ \\
Generation $\times$ Competition & 1 & 0.009 & 0.9 \\
Provenance $\times$ Competition & 2 & 0.026 & 2.8 \\
Gener. $\times$ Prov. $\times$ Compet. & 2 & 0.000 & 0.0 \\
Error & 77 & 0.009 & \\
\hline & & & \\
\hline P & & &
\end{tabular}

${ }^{*} P<0.05,{ }^{* *} P<0.01,{ }^{* * *} P<0.001$. environmental uncertainty ('adaptive bet hedging' sensu Clauss \& Venable, 2000; Volis, Mendlinger, \&Ward, 2004).

The present study was not designed to specifically test for local adaptation in germination traits, but the comparison of provenances across various environments (early spring vs. late spring, competition vs. non-competition, growth chamber vs. field) will indicate an adaptation to specific habitat conditions if the provenance ranking differs between environments. Such a link between differential provenance responses and habitat was found in several germination studies. Seeds from highland populations of Turkish weed species had a wider optimum and a lower minimum temperature of germination than seeds from lowland populations (Özer, 1996). Fluctuating temperatures enhanced germination of Fjellfield populations of alpine Potentilla matsumurae more than germination of snowbed populations which could be related to longer snow cover at the latter site reducing differences in temperature (Shimono \& Kudo, 2003). In relation to maximum germination in growth chambers, field germination of herbs used for ecological compensation in Switzerland was the highest for the local provenance and decreased with increasing distance of the provenance (Keller \& Kollmann, 1999).

Despite a remarkable degree of population differentiation, our study revealed surprisingly consistent germination percentages and times across the broad range of environmental conditions. For example in $O$. vulgare, the environment (simulated early spring vs. late spring, growth chamber vs. field, competition vs. noncompetition) had a strong effect on germination
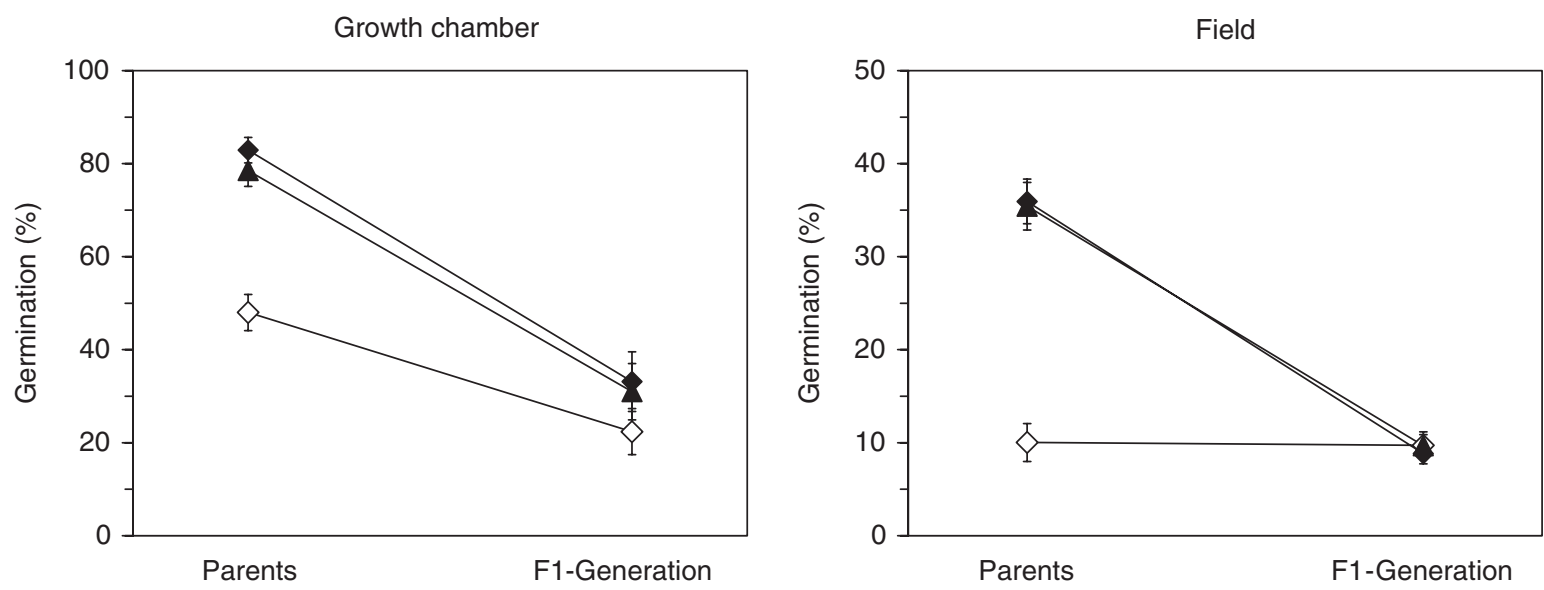

Figure. 4. Seed provenance effect on germination in the parental generation of Legousia speculum-veneris and in the F1 generation produced under identical conditions in common garden plots; data pooled for climate (growth chamber) and competition (field); $\diamond$, West $\mathrm{CH}$; $\diamond$, East $\mathrm{CH} ; \boldsymbol{\Delta}$, South $\mathrm{D} ; \pm \mathrm{SE}$. 
percentages, but the ranking of populations remained largely stable. The order of provenances was species-specific but there was a tendency of lower germination in the western European provenance. There was no general difference in the germination of seeds from commercial suppliers and hand-collected seeds. In three out of four species growth chamber trials gave reliable information about relative patterns of germination in the field, although germination percentage varied considerably between growth chambers and field. An exception to this general pattern was observed in $E$. vulgare, which showed a superiority of the local Western Swiss provenance in the field whereas germination in growth chambers was only average. A better adaptation to the local environmental conditions is a probable explanation for this result but due to the described limitations other causes cannot be entirely excluded. At least in the chosen system a high initial germination is a clear advantage because dormant seeds have low chances to successfully germinate after establishment of the plant community.

The generally high stability of the provenance ranking indicates that the observed differences may not be the result of an adaptive response to different environmental conditions and that processes other than selection are responsible for population differentiation. Several studies have shown that effects of genetic drift and inbreeding are particularly pronounced in small and isolated populations (Fischer \& Matthies, 1998; Hooftman, Billeter, Schmid, \& Diemer, 2004; Vergeer, Rengelink, Copal, \& Ouborg, 2003). In Western Switzerland, the test species are quite common (except for $L$. speculum-veneris) but they usually occur in small populations and fragmented habitats. A negative relationship between population size and fitness-related traits, including germination was found in species restricted to such fragmented habitats (Luijten, Kéry, Oostermeijer, \& den Nijs, 2002; Vergeer et al., 2003). Differences in population size and inbred level may also have been the reason for the inferiority of local populations that was found at a part of the sites in most multisite experiments on local adaptation (Galloway \& Fenster, 2000; Etterson, 2004; Joshi et al., 2001). The "cryptic" invasion of an introduced Phragmites australis genotype is a striking example for the possibility of superior alien provenances (Saltonstall, 2002). However, drivers for adaptation may be occasional events that are difficult to test in experiments (e.g. risk of late frost) and non-genetic effects (e.g. maternal environment) also contribute to population differentiation.

\section{Non-genetic effects}

It is well known that germination characteristics are not only affected by the current environmental conditions but also by conditions experienced by mother plants in the previous generation (Baskin \& Baskin, 1998; Donohue \& Schmitt, 1998; Roach \& Wulff, 1987). There are positive effects of maternal resources (nutrients, water, light) on germination due to increased allocation into endosperm and embryo (Galloway, 2001; Roach \& Wulff, 1987). However, the relation between resource availability, seed size and germination is constrained by many trade-offs (e.g. seed size-seed number, -predation, -dispersal) and there is also evidence for an increased seed mass in stressful, competitive environments (Donohue \& Schmitt, 1998). Moreover, non-resource factors like temperature and daylength during seed development affect dormancy and subsequent germination (Roach \& Wulff, 1987). They also act after harvest resulting in an effect of storage conditions on dormancy (Baskin \& Baskin, 1998; Gutterman, 1992). Finally, processing (harvest, cleaning techniques) of seeds by seed companies (quality assurance) constitute an additional source of non-genetic variation compared to manual collection.

In our study, companies had to guarantee that seed samples represent all size classes and, indeed, no general differences between seeds from companies and manual collection were found. Furthermore, selection of large seeds must not increase germinability. One of our test species ( $E$. vulgare) showed a negative relationship between individual seed mass and germination percentage, while in two other species (C. intybus, $O$. vulgare) this relation was positive. In all test species, fitting of seed mass as a covariate did not markedly change the significance of the provenance effect indicating that seed mass did not much contribute to differentiation of germination percentage. However, the parental environment might affect germination and early growth independent of seed size (Galloway, 2001; Montalvo, 1994) and therefore the comparison of original parental seeds and F1 seeds from plants grown under homogeneous conditions allows a more conclusive test of non-genetic effects.

The significant interaction of generation by provenance in both the growth chamber and the field indicates a non-genetic component of provenance differences in $L$. speculum-veneris. Germination percentage of two provenances supplied by seed companies strongly decreased from parental to F1 seeds whereas germination of the hand-collected western Swiss seeds remained 
constant (field) or decreased much less (growth chamber). The between-generation decline of the commercial seed, however, was exactly parallel and their ranking remained stable suggesting that much of the variation between provenances had a genetic basis.

\section{Conclusions}

Our study clearly demonstrates that seed provenance matters in restoration and habitat creation. Large between-provenance differences were found in the examined germination traits. It can be assumed that such provenance differences on germination strongly affect the early development of the target community and thus the success of short- and medium-term ecological compensation areas such as wildflower strips. The provenance ranking was found to be highly species-specific which might result in a failure of individual species if an inappropriate provenance is chosen. There was no evidence for a generally higher field germination of local provenances, and in three species, at least two of the non-local provenances germinated better than the local ones. However, a superiority of non-local provenances may also have negative effects because such provenances may become invasive. They may replace autochthonous populations, produce superior hybrids with local genotypes or spread into habitats that were not previously occupied by the species (Hufford \& Mazer, 2003; Saltonstall, 2002). Hence, both inferiority and superiority are an indication against the use of non-local provenances and only low genetic differentiation would be less problematic.

The ranking of provenances was largely stable across various environmental conditions and in most cases growth chamber tests allowed a reliable prediction of between-provenance differences in the field. This surprisingly high stability of germination traits is important information for evaluating seed provenances in restoration or habitat creation practice. Non-genetic effects were found to influence between-population differentiation. They have to be considered in testing provenances and in evaluating their suitability for restoration by sowing. Due to the potential importance of germination traits in plant development and vegetation establishment, and due to large betweenprovenance differences found in these traits, we strongly advocate to include germination in basic and applied studies on plant provenance differentiation.

\section{Acknowledgements}

We thank Franziska Leuenberger for assistance in the lab and in the field, particularly for preparing the huge amount of seed. We further thank Silvia Rauch and Stefanie Michler for their help in the field. Jacques Studer and Corinne Fankhauser helped in finding source populations for seed collection and a suitable field site. Wildflower strip mixtures were sponsored by Fenaco ltd. The study was funded by the Swiss National Science Foundation through the National Centre of Competence in Research (NCCR) "Plant Survival".

\section{References}

Baskin, J. M., \& Baskin, C. C. (1998). Seeds. Ecology, biogeography, and evolution of dormancy and germination. San Diego: Academic Press.

Bennington, C. C., \& McGraw, J. B. (1995). Natural selection and ecotypic differentiation in Impatiens pallida. Ecological Monographs, 65, 303-323.

Bossdorf, O., Prati, D., Auge, H., \& Schmid, B. (2004). Reduced competitive ability in an invasive plant. Ecology Letters, 7, 346-353.

Clauss, M. J., \& Venable, D. L. (2000). Seed germination in desert annuals. An empirical test of adaptive bet hedging. American Naturalist, 155, 168-186.

Cousens, R., Armas, G., \& Baweja, R. (1994). Germination of Rapistrum rugosum (L.) All. From New South Wales, Australia. Weed Research, 34, 127-135.

Donohue, K., \& Schmitt, J. (1998). Maternal environment effects in plants: adaptive plasticity. In T. A. Mousseau, \& C. W. Fox (Eds.), Maternal effects as adaptation (pp. 137-158). Oxford: University Press.

Etterson, J. R. (2004). Evolutionary potential of Chamaerista fasciculate in relation to climate change. I Clinal patterns of selection along an environmental gradient in the Great Plains. Evolution, 58, 1446-1458.

Fischer, M., \& Matthies, D. (1998). Effects of population size on performance in the rare plant Gentianella germanica. Journal of Ecology, 86, 195-204.

Galloway, L. F. (2001). The effect of maternal and paternal environments on seed characters in the herbaceous plant Campanula americana. American Journal of Botany, 88, 832-840.

Galloway, L. F., \& Fenster, C. B. (2000). Population differentiation in an annual legume: local adaptation. Evolution, 54, 1173-1181.

Gutterman, Y. (1992). Maternal effects on seeds during development. In M. Fenner (Ed.), Seeds: The ecology of regeneration in plant communities (pp. 27-59). Melksham: Redwood Press.

Hamilton, N. R. S. (2001). Is local provenance important in habitat creation? A reply. Journal of Applied Ecology, 38, 1374-1376. 
Hooftman, D. A. P., Billeter, R. C., Schmid, B., \& Diemer, M. (2004). Genetic effects of habitat fragmentation on common species of Swiss fen meadows. Conservation Biology, 18, 1043-1051.

Hufford, K. M., \& Mazer, S. J. (2003). Plant ecotypes: genetic differentiation in the age of ecological restoration. Trends in Ecology and Evolution, 18, 147-155.

Joshi, J., Schmid, B., Caldeira, M. C., Dimitrakopoulos, P. G., Good, J., Harris, R., et al. (2001). Local adaptation enhances performance of common plant species. Ecology Letters, 4, 536-544.

Keller, M., \& Kollmann, J. (1999). Effects of seed provenance on germination of herbs for agricultural compensation sites. Agriculture, Ecosystems and Environment, 72, 87-99.

Keller, M., Kollmann, J., \& Edwards, P. J. (2000). Genetic introgression from distant provenances reduces fitness in local weed populations. Journal of Applied Ecology, 37, 647-659.

Kindell, C. E., Winn, A. A., \& Miller, T. E. (1996). The effects of surrounding vegetation and transplant age on the detection of local adaptation in the perennial grass Aristida stricta. Journal of Ecology, 84, 745-754.

Linhart, Y. B., \& Grant, M. C. (1996). Evolutionary significance of local genetic differentiation in plants. Annual Review of Ecology and Systematics, 27, 237-277.

Lopez, G. A., Potts, B. M., Vaillancourt, R. E., \& Apiolaza, A. (2003). Maternal and carryover effects on early growth of Eucalyptus globulus. Canadian Journal of Forest Research, 33, 2108-2115.

Luijten, S. H., Kéry, M., Oostermeijer, G. B., \& den Nijs, H. C. M. (2002). Demographic consequences of inbreeding and outbreeding in Arnica montana: A field experiment. Journal of Ecology, 90, 593-603.

Montalvo, A. M. (1994). Inbreeding depression and maternal effects in Aquilegia caerulea, a partially selfing plant. Ecology, 75, 2395-2409.

Montalvo, A. M., \& Ellstrand, N. C. (2001). Nonlocal transplantation and outbreeding depression in the subshrub Lotus scoparius (Fabaceae). American Journal of Botany, 88, 258-269.

Nagy, S. E., \& Rice, K. J. (1997). Local adaptation in two subspecies of an annual plant: Implications for migration and gene flow. Evolution, 51, 1079-1089.
Özer, Z. (1996). Untersuchungen zu Keimtemperaturen von Unkrautsamen aus unterschiedlichen Gebieten der Turkei. Journal of Plant Diseases and Protection, Special Issue, XV, 61-64.

Pico, F. X., Ouborg, N. J., \& van Groenendael, J. M. (2003). Fitness traits and dispersal ability in the herb Tragopogon pratensis (Asteraceae): decoupling the role of inbreeding depression and maternal effects. Plant Biology, 5, 522-530.

Pons, T. L. (1991). Dormancy, germination and mortality of seeds in a chalk-grassland flora. Journal of Ecology, 79, 765-780.

Roach, D. A., \& Wulff, R. D. (1987). Maternal effects in plants. Annual Review of Ecology and Systematics, 18, 209-235.

Saltonstall, K. (2002). Cryptic invasion by a non-native genotype of the common reed, Phragmites australis, into North America. Proceedings of the National Academy of Sciences, 99, 2445-2449.

Schütz, W., \& Milberg, P. (1997). Seed dormancy in Carex canescens: regional differences and ecological consequences. Oikos, 78, 420-428.

Shimono, Y., \& Kudo, G. (2003). Interspecific variation in seedling emergence and survival of Potentilla matsumurae (Rosaceae) between alpine fjellfield and snowbed habitats. Annals of Botany, 91, 21-29.

Swiss Federal Office for Agriculture. (2003). Agrarbericht 2003. RDV: Berneck.

Van Tienderen, P. H. (1992). Variation in a population of Plantago lanceolata along a topographical gradient. Oikos, 64, 560-572.

Vergeer, P. R., Rengelink, C., Copal, C., \& Ouborg, N. J. (2003). The interacting effects of genetic variation, habitat quality and population size on individual performance of Succisa pratensis. Journal of Ecology, 91, 18-26.

Volis, S., Mendlinger, S., \& Ward, D. (2004). Demography and the role of the seed bank in Mediterranean and desert populations of wild barley. Basic and Applied Ecology, 5, 53-64.

Volis, S., Mendlinger, S., \& Ward, D. (2002). Adaptive traits of wild barley plants of Mediterranean and desert origin. Oecologia, 133, 131-138.

Wilkinson, D. M. (2001). Is local provenance important in habitat creation? Journal of Applied Ecology, 38, 1371-1373. 